S-10-4，電子カルテシステムを応用した個人医療 情報開示と地域医療ネットワーク一乳腺診療を中心と して

重田メディカルセンター・乳腺センター・乳腺外科",,

龟田幕張クリニッグ

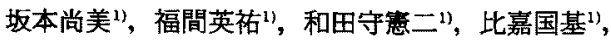
角田ゆう子2)

個人医療情報の開示や対等な立場で病診連携の必要性が いわれているが, そのためには時間格差, 情報量格荎のない 医療情報の交流が必要でる、当センターては1995年から

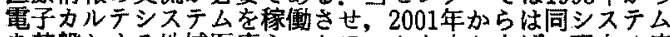
を基盤とする地域医療ネットワークを立ち上げ，現在 4 病 院, 14診境所とカルテ共有を扔こなっている.ネットワーク 施設で診撩を受けている患者が共有カルテに登録すること て, 同施設の医師は当セシタ一の医療情報を情報格差なし に得ることがてきる。共有カルテ参加者は現在約1800人、兄 らに馀痖に電子カルテを導入している施設の医療情報忏当 センターても確認が可能てあり, 真の意味の病診連携の構 筑ができると思われる。さらに2002年からは希望患者に電 子カルテの開示(PLANET)を開始し,自宅でも個人筷療情 報の閲覧が可能なシステムを構留した。現在かルテ開示の 思者数は約 1200 名。当セン多一の年間乳癌手術患者のうち

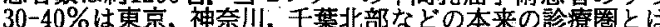
異なるから地域からの受診者である。放治, 化療を含めた安 全確寒な術後経過䮤祭のためにはネットワークの構築と患 者自身の医療情報への理解が必要である。遠隔ネットワー ク施設 3 ヶ所との連携, PLANET の運用を中心に, 䛦療情 報というプライバシー度の非常に高い個人情報に对卞るせ キュリティーマネシメシトシステム (BS7799を導入)をあ わせ当センターでの取り組みについて報告する。

S-10-5 地域医療支援遠隔病理診断，テレパソロ ジー：京都における13年の歩みと課題 ルイ・パストゥール医学研究センター臨床病理研究部 土橋康成

日本では病理医の数が少なく，多くの地域病院では，術 中迅速病理診断支援が満足に受けられないまま, 外科手 術を遂行しなければならない。この状況を改善すべく遠 隔病理診断システムの開発が取り組まれた。1991年春, 京都の日本医学会総会で, 衛星通信とハイビジョン動画 を用いた術中迅速病理診断の公開実験を組織し, 成功裏 に終了した。 その後 ISDN 回線と遠隔操作可能なロボッ 卜顕微鏡を用いた静止画䛦断システムの開発に民間企業 と共同で取り組み，数次の改良を経て，実用に耐える機 器の完成に至った。このシステムでは, 顕微鏡観察視野 移動, 倍率変換を裳隔操作で行え, 病理医の自由意志に 従った, 能動的診断が行える。またシステムの安全な運 用を目指すガイドライン作りも行われた，現在このシス テムを用いて，京都府下数病院の術中迅速病理診断支援 が行われて㭁り，地域医療支援に大いに役立っている。 2004年春には，経済産業省の支援で開発された，アーカ イブ機能付き，インターネット依存標準化テレパソロジ ーシステムのフィールド試験を，三重，京都，沖縄を結 んで行った。このシステムでは，テレパソロジーの適用 を, 病理診断コンサルテーションや細胞診，教育へと広 げることが出来る。一方こ机らIT 技術の進歩と成果に 適合した医療行政制度の改革は遅れており，その解決は 喫緊の課題であろう. 本発表では，IT に支えられた臨床 外科と病理のチーム医療の姿を述へたい。
S-10-6 心電図診断に関連する遠隔医療サービス 岩手医科大学第二内科・循環器医療センター 鐮田弘之

循環器領域の迋隔医療としては，心電図䛦断と心電図 以外の画像診断（心エコーや心葴カテーテルなど) に大 別される。動画像などを伝送する画像診断は実験として はおこなわれているものの，ビジネスとして提供できる 成鶖したサービスとなっていない。一方，心電図䛦断に 関連するものはビジネス化が進んできている.インター ネットビジネス用珸でいうところのいわゆる B to B (Business to business)として，ホルタ一心電図解析業 が挙げられる、これは通信でホルター心電図データを解 析センターに送り，解析結果を医療機関で受けとるサー ビスとして業務の効率化を目的としている．また，いわ ゆる B to C (Business to consumer) としては, 携带 型発作時心電図記憶伝送装置をもちいて患者が発作時に 医療機関に心電図を送るサービスに保険点数が認めら れ，新しい診療スタイルとして提供されている。同様に $\mathrm{B}$ to $\mathrm{C}$ として，家庭に設置した心電計を組み込んだ健康 管理機器をつかい，保健指導に役立てるテレケアとよば れるサービスが全国100ケ所以上の自治体に導入されて いる.特にテレケアは, 経斉産業省が中心となり健康サ 一ビス振興の組織を立ち上げるなど，普及のための国家 戦略が作られつつあり，医療のスタイルを変える産業と しての潜在力を感じさせる存在となっている.

これらの遠隔医療をめぐる全体の動きを俯㒈しつつ, 心電図に関連する遠隔医療サービスの現状と問題点と今 後の展望を述べる。

VS-1-1 下大静脈・肝静脈漫潤を伴う転移性肝癌 に対する積極的外科切除

千葉大学炡器制御外科学

木村文夫，伊藤博，清水宏明，安蒜聡，外川明， 大塚将之, 吉留博之, 加藤厚, 吉富秀幸, 澤田成朗, 宮崎勝

【目的】血管浸潤を伴う転移性肝癌に対する積極的外科 切除について検討した。【症例】転移性肝癌切除例は293 例て, 下大静脈合併切除が17 例(IVC群), 肝静脈合併切 除再建が 4 例(HV群)に施行された。【結果】IVC群の 原発巣は大腸癌15例, 胃癌, 子宫癌各 1 例. 界干切除術式 江右 3 区域 4 例，右葉 6 例，左葉 2 例，他 5 例。血行遮 断は THVEをII例に, IVC clampを 6 例に施行した。 再建は左鳌静脈を用いたパッチ再建 2 例, Ringed Gore Tex 1 例，縫合閉鎖を14例に施行した。出血量は 1050〜10715 (平均3388) g, 手術時間は277〜830 (497) 分であった。術後合併症の頻度は27\%に認め，5生率は $30 \%$ 対照で対照と差を認めなかった。HV群の原発学は 直腸癌 2 例, 結腸癌 1 例, 十二指腸 GIST 1 例. 切除術 式恬拡大否葉切除 2 例, S 1 切除 1 例, S 4 切除 1 例 $\mathrm{C}$, 肝静脈合併切除は MHV 1 例, RHV 2 例, LHV 1 例. 全例 patch 再建で graft は右精巣静脈 2 例, 脺静脈 1 例, 下腸間膜静脈 1 例であった. 出血量は420〜2200 (1555) g，手術時間は315 419(364)分. 全例街後経過良好. 術 後觀察期間は120１105(445)昌で, 残肝再発 1例, 直脂 癌局所再発 1 例である。【結語】下大静脈拀よび肝静脈浸 潤を伴う肝転移症例でも THVEなどの胡阻血法や静脈 再建を用いることで安全な切除が可能であり，その予後 も血管非浸润例での肝切除と変わらず，積極的に切除す ベきであると考えられた。 
VS-1-2 肝癌に対する個別化 ・低侵襲手術 磨應義塾大学外科

若林剛, 田辺稳, 上田政和, 島津元秀, 河地茂之, 北島政樹

肝癌の治療法として, 教室では個別化 - 低侵襲肝癌手術 という新しい概念を莩入している。原発性肝癌は背景肝 疾患による肝予備能から見た制限と多中心性発癌に見ら れる再発率の高さから，また転移性肝癌も肝転移紧がす でに遠隔転移であることから，低侵襲かつ局所根治的な 治療が求められる。腫瘍の進展と個々の患者の状態に合 わせて局所根治的な切除もしくは ablationを選択して, なおかつ個々の腫煌に対して最も適したアプローチ方法 (best approach)で体壁破壊を最小限に押さえて行う手 術を，個別化・低侵獎肝癌手術とする。 また ablation は マイクロ波, ラジオ波, cryoablation(凍結治療)から腫 境の大きさと存在様式を考慮して最も適した方法を選択 する (best modality). 腹腔鏡下肝切除術は表在 - 突出 型の肝癌に対して試行され，肝癌に対する低侵裂かつ局 所根治的な代表的治療である. 腹腔鏡下外側区域切除も da Vinci 使用することにより比較的容易に施行でき る.また, 経皮的に US 描出が困難な横隔膜下病変は胸腔 鏡下 ablation を選択する.一方， $5 \mathrm{~cm}$ 前後の大きな腫 癔で血管に接していても ablation が相応しい場合は凍 結治療が有用である。ささらに局所麻酔下経皮的凍結治療 は，ほとんど無痛で行える優れた低侵襲治療である。こ れら個別化 - 低侵襲肝癌手術のいくつかの手術手技をビ デオで供覧する。

\section{VS-1-3 当科における腹腔鏡下肝切除術の適応}

東京慈惠会医科大学附属柏病院外科 ${ }^{1}$, 東京慈恵会医科 大学外科 ${ }^{2}$

遠山洋一1), 孫敬洙 ${ }^{21}$, 䔳葉輝之"), 吉田清哉 ${ }^{21}$, 中里雄一1), 三澤健之 ${ }^{21}$, 柳澤暁 ${ }^{1)}$, 柏木秀幸 ${ }^{1)}$, 平井勝也 ${ }^{2)}$, 矢永勝彦 ${ }^{2)}$

[目的] 当科でも腹腔鏡下肝切除を行い，低侵襲による 術後QOLの向上を目指した. [奶象］1999年より腹腔鏡 下肝切除を計18例党施行。内訳は男性14名, 女性 4 名,

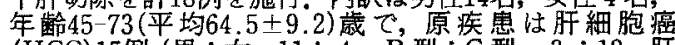
(HCC) 15例 (男: 女 $=11: 4, \mathrm{~B}$ 型: C 型 $=3: 12$, 肝 硬変: 慢性肝炎=13:2), 大腸癌肝転移 3 例(男:女 2 : 1). [方法] 術式は外側区域切除 2 例, 肝部分切除 16 例で, 占趣部位は $\mathrm{S}_{2 \sim 3}$ が 3 例, $\mathrm{S}_{3}$ が 2 例, $\mathrm{S}_{3-4}$ が 1 例,

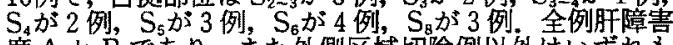

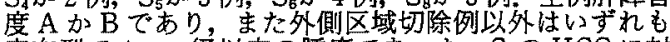
表在型で $4 \mathrm{~cm}$ 径以内の腫福であった。 方多経胸経横隔膜的アプーチの HALS 01 例を除 き, 他は全て腹腔鏡下切除で, 使用ポート数は 3 ports が 9 例， 4 ports はマイクロ波凝固併用加4例あり，それ以外はLSC と hemoclip あるいは刺入結督の combination で行った。

[結果] 術中出血量は32-680(平均74.6士49.4) g て, 手術 時間は50-410 (平均 $137.3 \pm 51.2$ ) 分. 術後合併症は胸水貯 留が 4 例のみ.術後在院日数は 5-24(平均 $12.8 \pm 7.9$ ) 日. 硬変合併例 2 例が多中心性発癌と䚽不全で各術後16r月 と31 ケ无死亡，宗た硬変合併 HCC 1 例が肝内再発 を, 大腸癌䚽転移例 1 例加大晹原発单局所再発をきたし たが, 断端再発例はない. [結論] 肝障害度 A か B C , 表在型 $4 \mathrm{~cm}$ 以内の腫煌あるいは外側区域切除が，腹腔 鏡下肰切除の良い適応と考えられた。
VS-1-4 肝癌治療に対する合理的肝切除の意義一 肝切除が最良の治療一

千葉県立佐原病院外科

竜崇正, 趙明浩, 高山亘, 小林進, 菅谷睦, 羽成直行, 岡田正, 服部憲幸

Couinaudは肝切除の入りロとして main portal fissure と umblical fissure $の$ 重要性を述べているが，われわれ は第3の入りロとして anterior fissureがあると考えて いる。これらの fissure から备垔区域グリソン枝に到達 して一括処理し，明らかになった阻血域のみを切除する 合理的方法を施行しているので報告する. 門脈 segmentationからいえば前区域はS 5 とS 8 ではなく,腹側区 域と背側区域に分けられるべきであり，前腹側区域のド レナージ静脈は中肝静眽に流入し，前背側区域はドレナ ージ静脈は右肝静脈に流入する。そして背側区域と腹側 区域の間を anterior fissure vein が走行し，中肝静脈根 部に流入する。この anterior fissure vein 走行部が anterior fissureであり，合理的肝切除をする上でもつとも有 用な fissure である. 我々の新しい合理的肝切除法は肝 腫漡支配グリソンを肝門部から各 fissure を開いて一括 でテーピングし，試験的に血流遮断する. そして阻血域 に沿って肝切離を開始し, 肝静脈は区域の境界をかなら ずしも走行していないのて，その露出にはこだわらず, その切除筙囲の流出肝静脈を根部近くで処理することを 重点に置くというものである.これらの手技をビデオに て供覽する。

\section{VS-1-5 肝細胞癌に対するMRガイド下マイク 口波凝固療法}

滋賀医科大学消化器外科"), 滋賀医科大学 MR 医学研究 センター2)

仲成幸"，来見良誠1)，塩見尚礼"1，出村公一"1, 佐藤浩一郎 ${ }^{11}$, 山口剛 ${ }^{12}$, 遠藤善裕 ${ }^{12}$, 花沢一芳 ${ }^{1)}$, 谷徹 ${ }^{12}$, 森川茂廣 ${ }^{2)}$

【はじめに】当科では，肝細胞癌に対する低侵襲治療と して、オープン MRIを用いたりアルタイムナビゲーシ ヨンシステムによるマイクロ波凝固療法を施行してき た. MRガイド下マイクロ波凝固療法の最新の手技を紹 介するとともに治療成續と適広についても咅及する。方 法】2000年 1月より2004年 3 月までに肝細胞癌66症例82 結節に対し，MRガイド下マイクロ波凝固療法を施行し た。平均年紫65.8歳, Child-Pugh A：55症例, B：11症 例であった，腫㣀の存在部位により経皮的，胸腔鏡補助 による経胸腔的および腹腔鏡補助による経腹的にアプロ 一チした. 全ての治療は術中リアルタイム MR 画像と術 前に撮像した画像データにより再構成された三次元画像 の統合 navigationによりなされた。治療に対する評価 は, dynamic CT および dynamic MRにて行った.【成

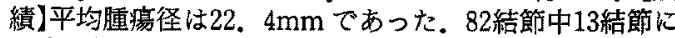
治療部位に再発を認め, 追加治療を要した。 3 年局所無 再発率は $80 \%$ であった.術後在院日数は中央值で 8 日( 3 〜21日)であった。【結論】肝細胞癌に対する MRガイド 下マイクロ波凝固療法は局所制御に優れ，術後在院日数 も短く，肝細胞癌に対する有効な治療戦略となり得る。 


\section{VS-2-1}

内視鏡下甲状腺切除術（前胸部アプロー

チ) の工夫

西新クリニック"), 九州大学臨床・腆瘍外科2), 浜の町病 院外科 ${ }^{3)}$

大島章1)，清水周次 ${ }^{2)}$ ，小島雅之 ${ }^{2)}$, 大城戸政行 ${ }^{3)}$, 竹田虎彦 ${ }^{21}$, 黒木祥司 ${ }^{21}$, 田中雅夫2)

[目的］当科では内視鏡補助下 (VANS：V 法) と内視 鏡下 (Breast approach：BA 法) の両術式を採用して いるが，手技の習熟とともにBA 法を施行することが增 えてきた. 今回, BA 法の工夫について述べる。［方法 と成績]1999年 9 月より2004年 3 月までに60例の鏡視下 甲状腺手術を施行, 良性腫瘍51例 (V 法37例, BA 法14 例)，バセドウ病 9 例 (V 法 2 例, BA 法 7 例)であった。 $\mathrm{BA}$ 法のポートを雨側乳輪上縁 $(20 \mathrm{~mm}, 10 \mathrm{~mm})$ と患側前 腋窝線上 $(5 \mathrm{~mm})$ とし整容性が向上した。バセドウ病で も術野が良好で，ポート追加の必要がなかった。皮下剝 離は皮下脂肪層の表在筋膜浅層直下を㓦離し正確に広顼 筋の背側に入ることと, 超音波凝固切開装置のフック夕 イプを使用することにより，皮弁形成が容易になり出血 も隇少出来た，前頝笳の正中を䋛切開し必要最小限に前 預筋の横切開を加えることにより，甲状腺の良好な簬出 と閉鎖時の筋層縫合を少なくすることができた。 上甲状 腺動静脈を実質浻いに超音波凝固切開装置で切離するこ とで結愁やクリップの必要がなくなった。[結論]以上の 工夫と手技の習熟により，BA 法がより施行しやすいも のになった。

VS-2-2 甲状腺，副甲状腺手術における5-ALA を用いた蛍光発光法による術中副甲状腺同定の検討 日本医科大学外科学第二・内分泌外科 ${ }^{11}$, 東京大学大学院 新領域創成科学研究所 ${ }^{21}$, 東京女子医科大学脳神経セン 夕一脳神経外科 ${ }^{3}$, 東京女子医科大学大学院先端生命医 科学研究所先端工学外科分野 41

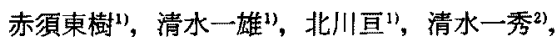

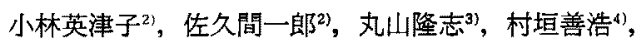
伊関洋4

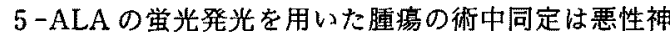
経膠腫をはじぬ広く用いられている，本法の副甲状腺へ の応用はラットで証明されているが，ヒトでの報告は無 い。我々は本法のヒト副甲状腺術中同定への応用を試み これまでに 4 例を経験した，方法は加刀3 時間前に5ALA $1 \mathrm{~g}$ 水溶液を内服させ, 術野を波長 $380 \mathrm{~nm}$ 以上で 光励起, カットオフ波長 $480 \mathrm{~nm}$ のフィルターを通して観 察方るというものである。症例の内訳は原発性副甲状腺 機能六進症 2 例, 二次性副甲状腺機能六進症 1 例，申状 腺乳頭癌 1 例である. 正常副甲状腺, 原発性副甲状腺機 能六進症の腫瘍以外の副甲状腺が明瞭な発光を示したの に対し, 腫瘍性, 過形成性副甲状腺では被膜上からはを らのある発光が誌められた。また割面に扔ける発光は被 膜を介するものより明瞭で，甲状腺等の周囲臓器から明 らかに視賞，明瞭化されることが確認された．簡便かつ 低侵襲の本法络副甲状腺疾患のみならず甲状腺手術にお ける正常副甲状腺の同定にも応用可能であると考えられ ๖.
VS-2-3 副甲状腺機能元進症に対する $99 \mathrm{mTc}$ MIBI guided Surgery 鹿児島大学大学院腫洎制御学

衣裴勝彦, 中野静雄, 上之園芳一, 有上貴明, 喜島裕子, 要甲孝

当科では，2000年11月より，原発性副甲状腺機能僬症 に対し $99 \mathrm{mT}$ TC-MIBI guided Surgeryを施行している. 本術式㹥術開始 2 時間前に投与し, $99 \mathrm{mTc}$-MIBI が集積 した副甲状腺を術中に GPS Navigator で同定し摘出す る. 現在20例にちいて $99 \mathrm{~m}$ Tc-MIBI guided $の$ 副甲状腺 摘出術を施行し，17例 (85\%)でRI が集積した病的副甲 状腺を術中に同定可能であった。病理診断は，全例で副 甲状腺腺腫であり，摘出10分後の intact-PTH は，術前 値の $23 \%$ まで低下し，ほ基準値となった. 血清 $\mathrm{Ca}$ 値も 速やかに低下し術後数時間で基準值まで低下した。この 術式は病的副甲状腺の局在を術中に同定可能であり，直 上の小切開創からの摘出が可能となり, 整容性について も優れていると考えられた.GPS Navigator を用いるこ とにより最短なアプローチでの摘出が可能になり，㓦雄 操作などによる術中, 術後の出血などの合併症を軽減さ せることが期待でき，また多腺腫大の病的副甲状腺の取 り残し防止においても有効であると考えられた．原発性 副甲状腺機能六進症に対 L $99 \mathrm{mTC}$-MIBI guided Surgery は合理的であり，低侵婧で有用な術式であると考え られた.

VS-2-4 3 D-CT lymphagraphy を用いた新し いセンチネルノードナビゲーションと鏡視下手技を用い た低浸襲な乳房温存裺法

山口大学消化器腫湟外科

丹黒章，山本滋，長島由紀子，岡正朗

センチネルリンパ節 ( (SLN) 同定法には色素法, RI 法が あるが，色素法は単独では同定率が低く，RI 法は施行で きる施設が限られて扔り, 術前 lymphoscinitigraphy 時間もコストもかかる。われわれは通常の造影剂を用い てSLN を周囲の解剖学的位置関係とともに立体的に描 出する 3 D-CTlymphagraphy (CTLG) 開発した。 【CTLGによるSLN 検索】遠隔転移検索のための胸・腹

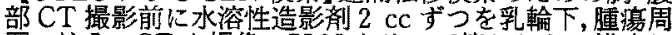
囲に注入，CTを撮像，SLNをリンパ管とともに描出し マーキングを行う.【手術手技】色素を乳輸皮下に注入し CTLG 像を基に SLN を局所麻醉下に摘出する. wide excision を行い, 永久標本にてマッピングを行う. SLN も細切し顕鏡する。この所見を基に IC を行い, 残存乳腺 に遺残が疑われるものは温存から除外，SLNに転移があ れば Level III までの en bloc 郭清を鏡視下に行う.【結 果】CTLGを50例に行い，SLN 同定率 $100 \%$ オ゙シパ管 とSLN の分析が可能であった。鏡視下手技を併用する ことにより局所麻酔下に迅速な SLN 生検, wide exci sionが可能であり, 正確な治療方針決定が可能であっ た.鏡視下郭清術により整容的にも満足できる創で精度 の高い郭清が可能であった。【結語】CTLG 証画期的な SLN 同定システムであり,鏡視下手術手技を駆使するこ とにより整容性と根治性を両立させた BCTを安心して 施行出来る。 
VS-2-5

乳癌センチネルリンパ節生検 - feasi-

bility study と clinical study の比較 -

日本赤十字社長崎原爆病院外科

中尾丞, 谷口英封, 中崎隆行, 田村和貴, 長谷場仁俊, 高木克典

【目的】当施設における RI・色素併用法（腫瘍直上皮下 局注)によるSLNB $の$ feasibility study $の$ 結果は, 同定 率96\%(64/67), 正䛦率98\%(63/64), 偽陰性率 7\%(17 14)であったが, この false negative がでる原因の 1 つ に, multi-lymphatic channel の存在が考えられる.こ のため informed consentを得て施行している clinical study ては, RI $の$ 局注箇所を增やL,SLN の個数や部位 について feasibility study と比較検討した。 (方法)腫㳻 径 $3 \mathrm{~cm}$ 以内, N 0 の乳癌症例 85 例 対 L, $99 \mathrm{mTc}-7$ 千

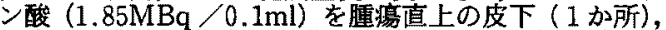

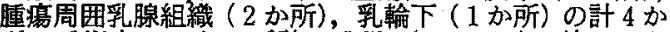
所に手術当日であれば計 $7.4 \mathrm{MBq}(0.4 \mathrm{ml})$, 前日であ れば計14.8MBq $(0.8 \mathrm{ml})$ を局注した。また手術開始10 分前に isosulfan blue $1 \mathrm{ml}$ 乳輪下に局注した.【成 續]SLN の同定率は92\% 個であり feasibility study と同じであったが, feasibility studyていみられなかつた internal mammary chain SLN 4 例, intramammary SLN 2 例, retromammary SLN 1例がみられた。【結論】乳腺のリ $ン ハ ゚$ 流は subdermal lymphatic channel $の$ 他に, retromammary lymphatic chnnel, intramammary lymphatic channel などの deep lymphatic pathway あるため, false negativeを少なくするためには本法の ように multi-channel を考慮したtracer の局注が合理 的と考光られる。

VS-2-6確実で容易に修得可能なセンチネルリン パ節生検手技をめざして（RI-dye 併用鏡視下センチネ ルリンパ䬣群生検)

川崎医科大学乳腺甲状腺外科

大久保澄子, 中島一毅, 園尾博司, 池田雅彦, 紅林渖一, 田中克浩，宇田川潔，廣納麻衣，野村長久

くはじめに〉現在，センチネルリンパ節 (SN)生検は臨 床上ほぼ日常化しつつあるが，信頼性が術者の経験に依 存し，修得に多数の経験を要するため導入さえ困難な施 設もある。当科では併用法 SN 生検の feasible study を 60例に実施，同定率98.3\%であったが，1例の偽陰性例 の経験から RI-dye 併用鏡視下センチネルリンパ節群生 検を考案，実施中である。この手技は偽除性を減らせる 可能性が高いだけでなく,初心者でも安全に修得し易く, 上記問題の解決につながると考えるので報告する。手 技〉 SNリンパシンチグラフィー：全例に ${ }^{99 \mathrm{~m}} \mathrm{Tc}$ c フチ ン酸注入，リアルタイム動画として SN へ流入するリン パ管の確認により SN を予測. 術中 SN 生㭘：鏡視下手 術に GPS を併用, 直線的に SN を検索. 鏡視下では ICG で緑染された複数りンパ管を確認，その収束するSNを 同定. 次に独自の工夫により鏡視下で SN を把持, 周囲 組織とともに体外へ誘導.GPSにてSN群をすへて同定 摘出, さらに残存組織内 $の$ RI 集積も確認, 取り残しを防 いでいる.く成績〉上記 study のうち20例に施行, 偽陰 性例なし．現在まで感度，転移陽性予測率とも $100 \%$ 。 結語>以上の手技は $2 \sim 3 \mathrm{~cm}$ の皮切で生検可能であ り，美容上有効であるだけでなく比較的短時間で安全に 修得が可能である。
VS-2-7 乳癌に対する高周波熱凝固療法

八尾総合病院ブレストケアセンター ${ }^{1)}$, 金沢大学医学部 附属病院手術部 ${ }^{21}$, 金沢有松病院外科 ${ }^{31}$, 金沢大学医学部 形態機能病理学(1)，富山医科蒋科大学第一病理学 51 江嵐充治 ${ }^{1)}$ ，藤井久丈 ${ }^{11}$, 野口昌邦 ${ }^{21}$, 横山浩-3); 原田憲一"4, 常山幸一 ${ }^{5)}$

乳癌の手術は縮小化する傾向にあるが，乳癌治療の将来 像は腫滇を外科的に切除することなく，乳癌を治すこと であるうと考えられる、今回，当該病院の倫理委員会の 承認之共に，患者と家族加らの書面による informed consent を得て原発性乳癌患者に対乙高周波熱凝固療法 を8症例に行なったので, 実際の手技と症例を提示する. 高雕熱㠜固療法はRITA Model 1500 RF 装置它 RITA Model 700 電極針 (Starburst - XL) (RITA Medical Systems, Inc., Mountain View, CA,USA) を用いて行った。術中，超音波ガイド下に電極針を腫滈 に刺入しその先端部より7本のアレイを腫崵内に展開

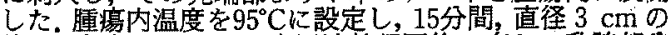
籍用で加熱凝固した，高周波熱凝固後，直ちに乳腺部分 切除術あるいは乳房切除術を行なった。術後, H\&E 染色 の組織検查では8例共に癌細胞の変性を認めるのみであ

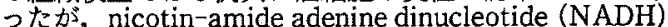
-diaphorase 染色を行なった 6 例では癌細胞が全く染 色されずその viabilityが完全に失われており，高周波 熱凝固潦法性乳癌の非手術的治療法として有効であると 確認された。現在, 乳房温存療法が広く, 普及している が, 高周波熱凝固療法十七ンチネルリシハ節生検十放射 線療法は”究極の乳房温存療法" と考えられ，将来，手 術的切除を希望しない乳痛思者に行なえる可能性が示唆 された。

\section{VS-2-8 乳癌に対するラジオ波炕療法の意義}

りんくう総合医療センター市立泉佐野病院外科 ${ }^{11}$, り くう総合医療センター市立泉佐野病院病理 ${ }^{2\}}$, 大手前病 院 ${ }^{3}$

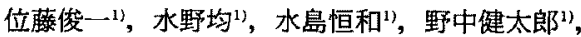
井手春樹 ${ }^{11}$, 道浦俊哉1), 甲斐沼尚"1, 山中宏晃"1, 山東勤弥 ${ }^{1)}$, 岩瀬和裕 ${ }^{13}$, 今北正美 ${ }^{2)}$, 有馬良一 ${ }^{3)}$

【目的】乳癌に対するラジオ波焼灼療法 (RFA)の有用性 を検討する。【対象および方法】針生検にて診断した乳癌 症例16例を対象とした。年柃は $42-87$ 歳(平均60歳)。腫 鹪径は1.0-3.2cm (平均 $1.6 \mathrm{~cm}$ ). 使用した電極は Radionics 社製 cool-tip 型. エコーガイド下に電極を睡 場内に刺入. 焼灼時間は 9 分一 49 分, 出力は $5 \mathrm{~W}$ より開 始し最大 $50 \mathrm{~W}-120 \mathrm{~W}$ まで增加. 焼灼後に腫演内温度を 湘定した. RFA 施行後の効果判定は造影エコー, CT, MRIのいずれかのダイナミックスタディにて施行. 同意 の得られた症例では腫淿部の14G 針生検またはマンモト 一ム生検を行った. 合併症の有無等安全性に関しても検 討した。【結果】焼为後の腫湯内温度は全例 $60^{\circ} \mathrm{C}$ 以上であ つた. 術前にエンハンスされた腫瘍部は RFA 後にはエ ンハンスされなくなった.RFA 施行後の組織診断ては 1 例のみに㭁いて腫癔周辺部に一部 viableな癌細胞を証 めた.焼灼後には同部の腫脹を認め，1例に揖いては 2 度 の皮虙熱傷を認めたが, 疼痛は自制内であった。乳癌治 療におけるRFAの今後の展望および問題点にも触れて 述べる予定である。 
VS-3-1 右側結腸進行癌に対する腹腔下手術手技 上の工夫（内側アプローチ変法）と手衡成績そして展望 広島大学先進医療開発科学 - 外科学

惠木浩之，岡島正純，池田聡，石崎康代，栗原毅， 吉满政義, 沖山二郎, 徳本憲昭, 小川尚之, 倉吉学, 川挥勝史, 浅原利正

<目的>右側結腸癌に対する腹腔鏡下手術手技上の工 夫，特に進行嵒に対する 3 群りンパ節郭清の手技と成續 を示卞。<方法>十二指腸水平脚右側前面を覆う薄い膜 を切開して十二指腸を背側に㔀離した後に，後腹膜下筋 膜前面と結腸間膜との間を安全に剥離している(内側 プロー手変法). 進行癌に対しては Surgical trunk を露 出し, その前面のりシハ節郭清操作を Surgical trunk 左 緑から胃結腸静脈幹の高さまで行っている(3群りンパ 節郭清).腹腔鏡下大腸切除術導入当初の1995年は適応を 早期癌に限定していたが, 1998年からはSS(A 1),N 1 (十)まてを腹空鏡下手術の適応としている。そこで1998 年加ら2002年までに右側結嗄癌に対して腹腔鏡下大腸切 除衍施行した33例のうち早期癌を除外した11例の成續 を，腹腔鏡下大腸切除術導入以前の1992年から1994年の 右側結腸癌手術症例 24 例のうち同様の手術適応を満たし 且つ早期癌を除外した13例を対象として検討した(Kaplan-Meier 法). <結果>腹整鏡下手術群 $(n=11$ : 平均 䫏察期間 32.64 的)の累積生存率は 5 年で $90.1 \%$, 開腹 手術群 $(\mathrm{n}=13$ : 平均観察期間 68.93 万月) $61.5 \%$ と 車群間に有意差は証めず $(p=0.5516 \log \mathrm{rank})$, む 腹腔鏡下手術群で良好な傾向にあった。く結諭〉腹腔鏡 下大腸切除術で3群りンパ節郭清を行うことは可能であ り，その成續は開腹手術と比較して決して劣るものでは なくさらなる発展を迎えるべき手術手技である。

VS-3-2 進行大腸癌におりる腹腔鏡下手術の適応 と成續〜497例の経験から〜

帝京大学付属㴗口病院外科

須田直史, 宮島伸宜, 村田宣夫

（目的）腹腔鏡下大腸切除術は，進行癌に対しては保険 適応になった現在でも遠隔成續の分析が示されていない ため，施設による適応にコンセンサスが得られていない のが現状である。我々は進行癌に対しても積極的に腹腔 鏡下手術を採用しており，その手技と成績について検討 しその妥当性を検討した（対象と方法)1992年 4 月から 2004年3月31日までに562例の大腸疾患に対して腹腔鏡 下手術を施行した。手技の変遷抢よびそれに伴う手術時 間, 偶発症, 合併症, 術後再発について検討を行った。 562例の内, 大腸癌は497例88.4\%)で, 早期癌は 134 例 (26. 9\%) 進行癌は363例 (73.1\%)であった。 Stage 分類では stage 0,1 が198例, stage $2 か ゙ 136$ 例, stage 3 a が101 例, stage $3 \mathrm{~b}$ が31例, stage 4 が31例であった[考察杇 よび結語]進行大腸癌に対する腹腔鏡下手術は, 偶発症, 合併症，5年生存率を各 stage 別にみても現時点では, 開 腹術でいわれている結果とほほ同等であり，進行癌でも 適応になりうる。また腫瘍占拠部位で適応決定に影響を 与えないと考えるが stage $3 \mathrm{~b}$ 症例の集積は必要であ る。腹腔鏡下手術が開腹手術と同等の地位を築くために は症例の集積とRCT が必須でありそれまで法術前診断 て stage 2 程度まで症例が一般的であると考える。
VS-3-3 進行大腸癌に対する腹腔鏡下リンパ節郭 清および腆瘍局所制御 大阪市立総合医療センター消化器外科 福長洋介，東野正幸，西口幸雄，谷村慳哉，岸田哲， 西川正博, 玉森量, 中澤一憲, 尾方章人，藤原有史， 小川雅生

【はじめに】当院における腹腔鏡下大腸切除術（LAC） 323例中進行癌は216例である。.回左右進行大腸癌に対 する 3 群リンパ節郭清と SE 腫淿に対する腫瘍局所操作 をビデオで供覧しその成績を検討した、【手術手技】いず れも後腹膜剝離先行内側アプローチを行う。右側では, 回結腸血管根部で SMV/A を露出した後トライツ䩗带 をランドマークとして頭側に郭清を進める。中結腸動脈 根部周囲の郭清後に右枝を切離する。左側では，左右腰 内臓神経の内側で大動脈外膜を露出し結腸間膜への神経 束を切離しながら IMA 根部に至る. SE が疑われる Rs/ a の進行癌では, 腫場口側の直腸を系で㹈引することで 腫場への直接の接触を防止した。【結果とまとめ】姑息切 除を除く208例にD 3 を施行した. 根治度 A 症例の再発 例は11例で死亡例は 4 例, 再発形式も LAC 特有のもの はなく，予後においても開腹例と差はなかった. Ra 進行 癌で LAC 尊入初期症例の 1 例に局所再発を認めたが, 上記手技を行ってから局所再発は無い. StageIV 症例18 例中, 局所の根治切除を行った13例て早期に他蔵器ある いは全身への化学療法が可能となり,局所/リンパ節再発 は無い.

\section{VS-3-4} 肥满例の進行大腸癌に対する腹腔鏡下手 術 自治医科大学大宮医療センター外科 河村裕, 斉藤正昭, 神崎雅樹, 小西文雄

【目的】腹腔鏡手術は開腹手術と比較して技術的難易度 が高いが,特に肥満症例では手術操作がより困難であり， 定量的尺度に基づいた肥満度の評価法の確立と, 手衍成 續の評価が必要である。本研究の目的は腹腔内の脂肪量 と，手術の難易度，合併症発生率との関連を明らかにす ることである。また，肥満症例における技術的な問題点 をビデオを用いて供覽する.【対象と方法】腹腔鏡下 S 状 結腸手術を施行した連続した43例を対象として，術前に 行った CT 検查のデータを用いて腹腔内の脂肪量を計測 した. 臍のレベルで，脂肪の CT 值を-100から40までを として腹腔内の脂肪の面積を計測した。腹腔内脂肪の多 寡により患者を 2 群に分けて，短期手術成績を比較した。 【結果】 2 群の腹腔内脂肪面積は平均 $95.8 \mathrm{~cm}^{2}, 219.7 \mathrm{~m}^{2}$ であった。肥満症例では, 視野の確保, 解剖学的メルク マールの確認がともに困難であった．手術時間，術中出 血量には，両群間で有意差を諗めなかったが, 開腹移行 率は肥満群で有意に高かった。合併症としては,SSI が肥 満群で有意に多かった。【結語】腹部 CT 検査データを元 にした画像解析による腹腔内脂肪面積測定は，肥満が手 術の難易度に与える影響を評価する上で有用であると考 えられた，腹腔内脂肪の多い症例に関しては，手術に対 する習熟度を考虑して手術担当テームを編成する必要が あると考えられた。 


\section{VS-3-5 進行直腸癌に対する腹腔鏡下手術} 順天堂大学浦安病院外科

福永正釈，木所昭夫，射場敏明，杉山和義，永仮邦彦， 渡燠繁, 須田健, 吉川征一郎, 白濱彰彦, 井田夕紀子

我々は進行大腸㾋に対し腹腔鏡下大晹切除 (LAC) を積 極的に導入し，様久な政良を加え，結腸䑁の LAC は手 技，成績とも安定してきた。しかし直腸癌に対しては骨 盤内低位ての操作, 直腸洗浄の問題, 吻合加困難なこと, 側方郭清の問題など解決すべき点がある. 直腸に対して も改良を加え，次第に適広拡大を図ってきた。現在，Rs は SE', A 1'まで, Raは明らかな SEてないもの, A 1' まで, Rbは MP'までである. 腫場径が大きいもの, 側方 郭清が必要と判断した場合, 他臟器漫潤がある場合は開 腹を原則としている，姑息的切除目的の症例导適応とし ている. mesorectal excision の層での剝離する症例には LAC は非常に有用な術式である。我々はLACを480例 施行し, 直腸澺は138例を経験した。開腹移行は 6 例で, 他器器浸潤疑いが 4 例, AW 追加切除のため 1 例, 腫煌 近接のため 1 例である. 尿管損傷など術中合併症は経験 していない，主な術後合併症は飤感染は 9 例あるが導入 初期に多く，最近は低率である。縫合不全 6 例で特に低 位での DST 吻合に改良すべき点がある．現在のところ 吻合部再発,ポート部再発は経験していない,今回は我々 の手技を中心にビデオを供覧する.

VS-3-6 進行大腸癌に対する腹腔鏡下手街

大阪医科大学一般・消化器外科

奥田準二, 山本哲久, 田中慶太朗, 西口完二, 近藤圭策, 菅敬治, 辰已嘉章, 谷川允彦

腹挖鏡下大腸癌手術では，no-touch technique を遵守 し，的確な部清操作を行うべく，内側アプローチを基本 手技とした。段階的に適応搪大し，減圧不能な腸閉塞・ 高度他臓器浸潤例や巨大腫㾇を除き，盲腸加部直腸 では SEまで、部直腸では A 2/N 1(t)までとして 腹腔鏡下自律神経温存側方郭清も開始L，511例（進行癌 319例) に蕧腔鏡下手術を施行した．右側進行癌にはSurgical trunk の形態をパターン化して合理的な D 3 郭清 を，遠位 S状結腸から直腸の進行癌には吻合部への血流 維持を目的に左結腸動脈温存のD 3 部清を行った。 た，上り安全で的確な部清とオーダーメードの血管処理 を行うへく Integrated 3 D-CT 画像を導入し, 周囲蔵 器との関倸も明らかとする Virtual surgical anatomy 人と発展させたが，とくに横行結腸癌に有用であった。 さらに，下部直腸癌では Prolapsing 法や経肘門的括約 筋部分切除法も応用して的確な肛門側腸管切離を行える ようにした。術後合併症は手技の効率化により減少した。 stage 4 卖除 $<494$ 例 0 万 519 例 ( $2: 3,3$ a: 10,3 b: 6)に術後䀒転移を等め, 12 例に肝切除を施行した。 局所/吻合部再発や創部/ポート部再発は認めなかった。 システム化された手技とTechnologyの導入により進 行大腸癌に対しても腹腔鏡下手術は根治性を落とさない 低僈堭筡外科治療として有用と考えられた。ただし，とく に下部直腸藻の肛門側腸管切離にはさらに器機の開発。 手技の工夫を重るていく必要がある。
VS-4-1

食道アカラシアに対する内視鏡手術と術

式の選択

日本大学消化器外科

山形基夫, 三上元，田中和彦，高山忠利

近年，食道アカラシアに対する内視鏡下手術はその手術 侵褺を柽減させ比較的早期に手術が施行されている。当 教室では腹腔鏡市術式として当初 Girard - 田中产法を 全例に採用していたが術後経過の検討からSpindle type $と$ Flask type $に$ Heller-Dor 法と Sigmoid type にはGirard 一田中変法を用いている. Girard 一田 中変法は Heller-Dor 法の筋愿切開を噴門側に延長し横 縫合を追加した術式であり，下部食道攧門部を直線化す ることてら型の萿後通障害による愁訴を軽減するの に有效です。. 我々の術式の特徴は筋愿を安全かつ確実 に切開でるる型フックを用いること, 剝離に LCS, 縫 合にEndostich, 結势に EZプッシャーをそれそれれ採用 し時間の短綰をはかったことであり, 現在手術時間は約 2 時間, 出血量 $50 \mathrm{ml}$ 以下となっている.現在をて27例の 患者に本法を施行しているが術後合併症は諮められてい ない.手術奻果については術後食道造影検查, 並びに食 道内压曲線にて評価した。全ての症例で術後食道造影上 食道横径の縮小と通過障害の改善が認められ, 食道内圧 曲線上も静止圧の低下と飲水負荷試験の正常化が観察さ れた. しかし, Grade 304 例で性飲水負荷試験て涸下 後の内圧回復時間の延長が認められている。これは開腹 症例と比較してほほ同様の成績である。本法は手術機具 及び手技の進歩により開腹術と比較して十分安全で低侵 檽な治潦法として今後治療の第一選択となることが期待 される.

VS-4-2 胃食道逆流症拉よび食道裂孔へルニアに 対する腹腔鏡下噴門形成術

福山市民病院外科

井谷史哃，金仁洙，室雅彦，石川隆，石井辰明， まるやま昌信, 久保嫃一郎, 岩本高行, 渡趩伸一郎

1997年 5 月から2004年 4 月までに胃食道逆流症 (GERD) 34例および食道裂孔へルニア16例(type 3:15例)に対

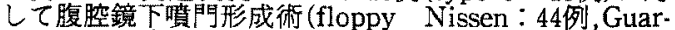
ner: 1 例,前方噴門形成：5例) 施行Lた. Los Angeles 分類 17例，D:13例であった。噴門形成術は Floppy Nissen 標準術式とし，高歯者 type 3 ヘルニアで十分な術前検 香ができない症例あるいはブジーの择入が困難な症例に 対しては Guarnerまたは前方噴門形成を施行した。手術 時間は126分で術後平均在院日数は7.6日であった。 Nis. sen噴門形成施行に際しては捻れが生じないように胃底

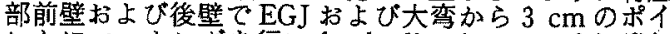
シトにマーキシグを行い fundoplicationでのそれそれれ 左側および右側の縫合点の指標とした。開腹移行はI例 $(2.4 \%) て ゙$ 術中心合併症として左側気胸を1例に諗め た. 術後軽度の嬹下困難を 3 例 $(6 \%)$ に認めた.中央值 42 力月の観察期間において全例生存中で著効41例(82. $0 \%$ ，有効 6 例 $(12.0 \%)$ ，無効 3 例であり，無効例のうち 2 例に再手術を要した。2 24時間 $\mathrm{pH}$ モニ多一 $(\mathrm{n}=16)$ て は酸暴露時間の有意な低下交諗めた(術前 $43.6 \%$, 術後 $12.8 \%, \mathrm{p}<0.0001)$. またビリテック(n=7)においても ビリルビン逆流時閒の減少を認めた(術前51.7\%,術後 $25.9 \%, \mathrm{p}<0.05)$. 以上により，腹腔鏡下噴門形成術は胃 食道逆流症および食道裂孔へルニアに対して安全かつ有 効な沿療手段だと考えられる。 
VS-4-3 合併症から見た胃十二指腸穿孔に対する 鏡視下手術の適応と限界

奈良県立医科大学救急科

畑倫明，村尾佳則，中村達也，小延俊文，關匡彦，

奥地一夫

【背景と目的】近年, 胃十二指腸穿孔に対する鏡視下手 術も広く行われるようになってきており, 今回我々は合 併症から見た適応と限界に関して検討した。

【対象と方法】1990年以降に当科入院した胃十二指腸穿 孔100例のうち,開腹あるいは鏡視下に大網充填術を施行 した88例について検討を行った。

【結果】衍後合併症は皮下膿瘍などの軽微なものを含め 88例中23例(26.1\%)に認めた。術後合併症の発生率は, 年齡では60歳以上 $41.9 \% ， 60$ 歳未満 $17.5 \%$ と高齢者に多 く, 発症一手術までの時間 $(\mathrm{n}=83)$ では $12 \mathrm{~h}$ 末満 $16.4 \%$, $12 \mathrm{~h}$ 以上 $40.9 \%$ と $12 \mathrm{~h}$ 以上に多加た。 また術前 CRP 值 $(\mathrm{n}=63)$ では $0.6 \mathrm{mg} / \mathrm{dl}$ 以上の陽性 $37.1 \%$, 陰性 $3.6 \%$ と CRP 陽性例に多く,術式では腹腔鏡 $(n=40)$ て $17.5 \%$, 開 腹 $(n=48) て 33.3 \%$ と開腹例に多く認めた。術前ショッ ク状態であった開腹症例を除き，発症〜手術までの時間 が12時間末渾の症例について検討すると腹腔鏡 $6.7 \%$, 開 腹 $25.8 \%$ と開腹例で高率であったが，12時間以上の症例 で検討すると腹腔鏡 $25 \%$ ，開腹25\%と差はなかった。

【考察】発症加ら12時間以上経過した高齡者で, 術前 CRP高値を示方症例が術後合併症のハイリスク群であ った．腹腔鏡のメリットは発症後の経過時間が12時間未 満の症例で顆著であると思われた。

VS-4-4 脾良性疾患に対する腹腔鏡下脾藏摘出術 は標準手術となり得るか.

大阪大学病態制御外科 ${ }^{1}$, 国立病院大阪医療センター外 科(2)

池田正孝 ${ }^{11}$, 関本貢嗣 ${ }^{11}$, 瀧口修司 ${ }^{11}$, 福永浩紀 ${ }^{11}$, 瀬下篇"1, 安井昌義"), 高山治"), 池永雅一2), 山本浩文"), 大植雅之" 門田守人”)

【目的】脾良性疾患に対する腹腔鏡下脾葴摘出術 (LS) の成續を解析し，LSの脾良性疾患に対する有用性を検 討する。【方法】LSを施行した脾腫を伴わない摘出脾重 量500g 以下の脾良性疾患患者64例の手術合併症, 術後合 併症，開腹移行率，術後在院日数を retrospectiveに検討 した.【結果】対象患者は特発性血小板隇少性紫斑病58例， 遺后性球状赤血球症 2 例, 自己免疫性溶血性賓血 1 例, 脾血管腫 1 例, 脾膿瘍 1 例, 脾霮胞 1 例. 摘出脾重量中 央値 $130 \mathrm{~g}(11 \sim 495 \mathrm{~g})$, 手術時間中央値124分 (55～345 分), 出血量中央值 $38 \mathrm{~g}$ (わずか〜 $2050 \mathrm{~g}$ ). 術後入院日数 中央値 9 日 $(4 \sim 22$ 日), 術中出血を 1 例に認めた。術後 出血は 3 例で, 内 1 例に輸血を要した。開腹移行ならび に再手術例なし. 前期22例, 中期21例, 後期21例の（手 衍時間中央值，出血量中央值）はそれぞれ，(168分，105 g)，(120分，40g)，(102分，20g）で, 術式に対する習熟 が見られたが，術後入院日数中央值は全期において 9 日 で差は無かった. 我々の行っている手術をビデオで供覽 する.【結論】LSにおいても術者の習買は重要である。 術者の習熟が得られた後は手術時間, 出血量が安定し, 十分に標準手術として成り立つと考えられた。
VS-4-5 謴湯性大腸炎に対する Liga-Sure Atlas を用いたClipless Hand-Assisted Laparoscopic Restorative Proctocolectomy

大阪労災病院外科"), 大阪大学葴器制御外科学 ${ }^{21}$, 日生病 完外科 ${ }^{3)}$

根津理一郎 ${ }^{11}$, 甲婓康之 ${ }^{13}$, 藤川正博 ${ }^{1)}$, 藤井溑 ${ }^{1}$, 前田庄平 "), 仲至永 ${ }^{1}$, 森島宏隆 ${ }^{1)}$, 山上裕子', 武本智樹 ${ }^{1}$, 宮訔安晃 ${ }^{1}$, 吉川澄1), 伊藤壽記 ${ }^{2)}$, 打越史洋 ${ }^{2)}$, 井上善文 ${ }^{31}$

【目的・対象】遗瘍性大腸炎 (UC) に対する大腸全摘・ 回腸肛門管吻合術 (IACA) において，1998年７月以降の 55例に対し $\tau$ Hand-Assisted Laparoscopic Surgery (HALS) を本術式に応用し，その有用性につき報告し てきたが，LCSおよび clipによる結腸間膜切離には長時 間を要する例もみられた。.今回, 2002年 4 月以降の25例 にLiga-Sure Atlas(LSA) を用い，その血管・間膜好理 に扔汀る有用性，安全性について検討した。【手術手技】 Lloyd-Davies 位, 下腹部に $7 \mathrm{~cm}$ 長の小開腹を行い, 脆 上部よりスコープ，左側腹部より LSAを择入し HALS 崺行, 結腸間膜の処理に血管結絷わよび clip は全く不要 であった。気腹操作終了後は全結腸を創外に引き出し， 直視下に直腸の剝離を行いDSTにてJ-pouch IACAを 行つた。【結果】気腹時間（上・不行結腸授動および大網, 結腸間膜切離) 72分 (43-135分) と LCS 使用時に比して 約40分短縮，総出血曾も $110 \mathrm{ml}(30-310 \mathrm{ml})$ と減少した。 合併症として再出血 1 例を動脈硬化を有する例に認め た。【結論】UCに对する HALS-IACA 時, 血管·間膜処 理に Liga-Sure Atlas を使用した。本器塄は cavitation の riskもなく，簡便に clipを用いることなく間膜処理 が可能であったが，動脈硬化合併例では sealing 効果不 充分の可能性があり，注意が必要と考えられた。

\section{VS-4-6 潰韵性大腸炎に対する腹腔鏡下手術}

北里大学医学部外科

大谷㓮正, 根本一彦, 中村隆俊, 佐藤武郎, 小澤平太, 國場幸均, 井原厚, 渡邀昌彦

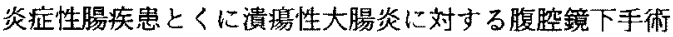
の経験と手術にちける合併症回避のための工夫とポイン トにつき報告する.【対象】潰滨性大腸炎手術例は178例。

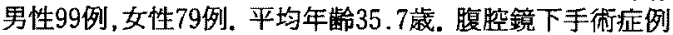
は41例，回腸肚門管吻合34例，直腸粘膜抜去.回腸肛門吻 合 4 例，回腸直腸吻合 2 例，大腸全摘. 回腸人工肘門 1 例 であった。腹腔鏡下手術の適応は待期手術症例とし，緊急 手術は開腹分割手術としている.【合併症回避のポイン 卜】1,静脈血栓の予防と褯創の予防を行う。皮阅脆弱で あるので固定器具が直接皮凰に接触しないようにする 2 , 獎膜炎と組織脆弱性が強く,限りなく愛護的操作が必 要 3 ，腸管の授動と血管処理：㵊も炎症が強く，剝離操作 が難しい脾弯曲部を最初に完全授動する．腸管膜血管処 理は vessel sealing systemを用いて切離するが, one clip 後に切㒕する4 , 直腸周曲刹離は超音波切開凝固装 置や vessel sealing system を用いる. 直腸右側から前後 壁を虽離し、左側は最後に切離していく5,肛門举筋は確 認するのみで切離しない，6，肛門管切離時,前壁は少し 長くなるように，後壁は歯状線にかかるようにするて， DST 時,肛門管損傷に最も注意する。 


\section{VS-5-1}

標準術式としての腹腔鏡下順行性胆露摘

出術

大阪労災病院

藤川正博, 根津理一郎, 藤井貞, 前田庄平, 甲斐康之, 仲至永, 森島宏隆, 山上裕子, 武本智樹, 宮岦安晃, 吉川澄

[目的] 胆霍を底部から頝部に向けて剶離し最後に胆篦 管を離断する順行性術式は，Calot三角の高度炎症例の みならず，炎症の乏しい症例で初心者が行う場合でも， 胆道損傷の防止という点でより安全である。これまで 我々は腹腔鏡下順行性胆囊䐱出術の有用性を報告してき た。今回その手術手技を供覧し，標準術式としての適否 につき検討した。 [万法, 手術手技]1999年 3 月から2003 年12月まで，研修医を含む複数の術者により施行された 腹腔鏡下胆堡摘出術完遂例 426 例を対象とし, 順行性 (263 例) と逆行性（163例）の間で, 胆道損傷の有無, 手術時 間につき比較検討した。手術は 3 or 4 ports下にまず 胆售管を仮クリップ, 可及的に胆襄動脈を切離後底部か ら顼部に向け順行性に胆衰を切離, 最後に胆霍管を確認, 切離した。 [結果]胆道損傷はいずれの群でも認めなかつ たが，䐓行性に行ったことで誤認による胆管の切断を回 避できた症例が 1 例あった。平均手術時間は順行性，逆 行性いずれも87分で有意差は認めなかった。［まとめ] 開腹術と同様の順行性胆揨摘出術は腹腔鏡下でも標準術 式として有用と考えられた。

VS-5-2 皮下鋼線吊り上げ法による腹腔鏡下胆翼 摘出術とその問題点

北里大学外科

星野弘樹, 古田一徳, 坂本友見子, 鹿取正道, 高橋毅, 吉田宗紀，佐藤光史，渡邊昌彦

当科では2001年12月より皮下鋼線吊り上げ法を莩入し， 約 120 症例を経験した。手術時間, 術中出血量, 開腹移行, コストについて検討し，気腹法に比べコストのみが著明 に有意 ( 8 割減)であった。

【術式】視野は2 本の䥠線で確保する，1本目は右朐骨 弓の約 2 横指頭側に，2本目は梳上に前者に垂直するよ うに挿入する。腹腔内操作はまず Hartmann's pouch(以 後 HP) 直下から開始する.HP を持ち上げ胆襄墏膜の左 右を十分に切開する。䟝離は胆菓の右後側加ら行い䅡部 が全周性に十分に持ち上がるまで㔀離を続け，この剝離 を中枢側に進めると自然と胆衰管は同定される，教育で は特にこの胆慗管の同定が重要であり，初めから“胆霓 管を造りにいく”という操作をしなければ胆管損傷はな い. 当科では直接造影を全例に施行している. 胆哓管切 開の要点は,繰り返す切離により内腔が不明瞭になる為, 1 回の操作で確実に約 $2 / 3$ 周を切開することである。

【問題点】最も問題となるのが視野不良である。鋼線は 筋膜直上に挿入するがこれが浅いと皮下が持ち上がるだ けで有効な腹腔内腔は得られない，特に肥満体型ではこ の傾向に陥りや寸い，導入当初は視野の確保に難步した 症例もあったが，鋼線位置の工夫により，現在，視野不 足は殆ど無い。
VS-5-3 腹腔鏡下胆犦摘出術の適応と限界 東海大学大磯病院外科 ${ }^{11}$, 東海大学消化器外科 ${ }^{21}$ 大谷泰雄 ${ }^{1)}$, 檜友や ${ }^{1)}$, 田島隆行 ${ }^{11}$, 中村知已 ${ }^{1)}$, 向井正哉 ${ }^{1)}$, 中崎久雄 ${ }^{11}$, 飛田浩輔 ${ }^{2}$, 堂脇昌一2), 石井正紀"), 今泉俊秀 ${ }^{2}$, 生越喬二2), 幕内博康 ${ }^{2}$

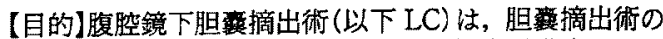
標準術式となったが種々の偶発症や合併症が発生してい る.特に重篤な合併症である胆管損傷を中心に検討した ので報告する。【方法】1991年 7月〜2003年12月までに経 験した LC 症例は1198例である.LC 開始当初は総胆管結 石・急性胆巽炎・上腹部手術既往などの症例は適応から 除外していたが手術手技の向上とともに1998年より適応 とした. 現在の術前画像の評俩はエコー及び MRCPま

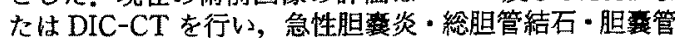
閉塞などの症例は ERCを施行し手術難易度が高いと判 断した症例には術前より non-EST下に 5 Fr-ENBD を㨉入し術中胆道造影を施行するようにしている。また 手技的には，Calot三角部の開大時に背面の肝蔵との付 着部を丁寧に虽離することを特に強調したい.【成績】 1198例中胆道損傷は 9 例(完全離断なく胆管消化管吻合 はなし)で全例に術中に発見し処置した.1998年以前には 8 例 $(8 / 571: 1.4 \%)$ の胆管損䂓を経験したが1998年以 降は1例(1/627：0.16\%)であった。【結諭】手術難易度 の高い症例をいかに見拔くかが重要で，腹腔鏡下手術を 安全に行うにはいつでも開腹移行する勇気が必要であ 万.

VS-5-4 総胆菅結石症に対する腹腔鏡下手術の基 本手技とその応用 名古屋第二赤十字病院外科

長谷川洋，坂本英至，小松俊一郎，広松孝，森俊治， 田畑智丈，河合清貴，深見保之，土屋智敬

われわれは1992年から総胆菅結石症に対する腹腔鏡下手 術を開始し，以後第一選択の術式として採用している。 この間の経験症例は278例であり,施行された術式の内訳 は胆管切開138例，経胆萑管127例であり，開腹移行は 4 例（1.4\%)であった。術式の選択基準は，落下結石では

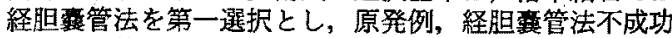
例では胆管切開を行っている。経胆霟管，胆管切開を安 全に施行するための基本的な手技，コツを供覧するとと もに，胆露管への胆道鏡挿入困難例，胆管非拡張例など に対する手技の工夫を紹介する。 また，これらの手技を 応用した合流部結石などに対する適応の拡大などについ ても報告する。 
VS-5-5 総胆管結石症の腹腔鏡下手術の手技と成

績

東北労災病院外科

鹿郷昌之, 徳村弘実

【目的】腹腔鏡下胆管切石術は手技が多様で難度が高い. しかし根治的, 低侵襲性と乳頭温存という利点を有する。 本手術277例の経験加ら手技，成績を紹介する。【手技】 経胆衰管法：術中胆道造影後，胆管を $6 \mathrm{~mm}$ バルーン 拡張. $2.8 \mathrm{~mm}$ 胆道鏡下にバスケット除石. 胆管切開 : 造 影後, 胆管切開し4.9mm 胆道鏡下にバスケット除石. 切 開部は連続縫合， Tチューブ例は結節縫合する。Cチュ ーブはエラスキック縫合系で固定.【適応】経胆管法は結 石が 4 個以下, 径 $8 \mathrm{~mm}$ 以下で肝側に結石がない例に選 択. この基準外は胆管切開し，切開部を䋖合閉鎖後 Cチ ューブ追加. 遗残が危惧されるときはTチューブを追 加.【結果】経胆霍管法を113例に完遂し手術時間は141分. 遺残結石, 再発結石が各 1 例. 誧後入院8.1日. 胆管切開 は139例で平均157分. Cチューブ91例，Tチューブ44例， 一期的綘合15例, 一期的縫合 +PTCD とど 9 例, 胆管十 二指腸吻合 1 例. 胆汁漏出は一期的縫合 5 例, Cチューブ 2 例. 遺残 2 例, 再発 4 例あった. 開腹移行は 4 例.【ま とめ】経胆管法の利点は大きい。 Lかし適応を限定せ ざるを得ない. 胆管切開は胆管非抎張例を除けば可能で あった。腹腔鏡下胆管切石術はほとんどの胆管結石症に 可能で優れた術後成績が得られた。

VS-5-6 腹腔鏡下胆裹摘出術（LC）にちける術中 胆管損傷に対する pitfall と対策

日本医科大学第 1 外科

有馬保生, 横室茂樹, 吉田寛, 野村務, 真々田裕宏, 相本隆幸, 谷合信彦, 中村慶春, 水口義昭, 清水哲也, 高橋翼，川東豊，田尻孝

【目的・対象】教室では1268例にLCを施行し，術中開腹 移行,術後再手術を必要とした胆管損傷を 5 例経験した. この 5 例の損傷原因を考察し，LC $の$ 胆管損傷に対する pitfall と対策について検討した。【結果】損傷部位と程度 は，胆锤管との誤諮による総胆管離断 1 例と部分損傷 1 例，胆䍿頝部前壁の剝離中の総胆管完全離断 1 例と右肝 管部分損傷 1 例, 電気メスの誤操作による胆管管部分損 傷 1 例であった。【pitfall・対策】胆霓管との愦認による 総胆管離断例は short cystic duct 症例で, 胆謽䅡部前壁 の剩離中の損傷例は非常に高度な炎症例でともに胆管損 傷を起しやすい. 対策は (1) 胆衰の墏膜を十分に副離 して受動をよくし，胆衰頚部から胆雚管への移行部を全 周性に别離する。その際，前後壁の移行部が見合う位置 にあることを十分に確認することが重要である。( 2 高 度炎症例では鈍的剥離を多用し, 電気メ不使用時は常に 胆管との位置関係を考虑し熱損傷の回避を心がける.

(3) 術中胆管造影を積極的に行う.【結語】胆衰頝部か ら胆霍管への移行部の全周性剥離と術中胆管造影ての胆 管の解剖学的位置関係の確諮は, LCにおける胆管損傷 の回避に重要であった。

\section{術}

(医) 涼友会神楽坂 D.S.マイクリニック・執行クリニッ

ク

小島伸, 執行友成, 松橋亘, 永田傳

【目的】胆石症は早い社会復帰により患者さんの経済効 果, 医潦費削滅に慗がる。手術当日朝入院, 午後手術, 夕食摄取し, 1 泊入院後, 翌朝退院卞る事が可能となる た. 2003年2月より14例のI泊入院を経験.【方法】手術 当日午前 9 時半まてに入院, 午後 1 時入室, 麻醉後脳内 より $5 \mathrm{~mm} ト$ トッカー挿入. 宸酸ガス気椱, 右側腹へ3 $\mathrm{mm}$ トロッカーを 2 本择入. 季肋部より $1.2 \mathrm{~cm}$ トロッカ

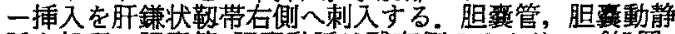
脈を処理. 胆襄管・胆亯動脈は残存側のみクリップ処置。 切除側はハーモニックスにて切断、凝固，胆襄周囲は電

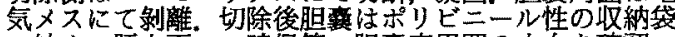
へ納め, 肝上面へ二時保管。胆襄床周囲の止血を碓認, 季肋部より取納袋ごと取り出す。胆衰や結石が大きい場 合は，収納袋内にて胆汁の吸引，結石の破壊を行うと容 易に取り出すことが出来る.ドレーンを入れず創は閉鎖. 創入局所麻酥薬を注入する。術後は下肢を間久的に压卞 ることにより血栓予防を行う. 術後 $2 \sim 3$ 時間にて引 氷・步行開始. 4 〜 5 時間にて二般食を経口摄取開始京 る.翌朝創確想ご退院。行動の制限は無い.【成續】14例 中前期 5 列 2 泊入院 (患者の不安) 後期 9 例 (ドレーン 無し)は1泊入院であった、【結論】胆计漏出による痛み はなく,術後の疼痛は局所麻酔楽を創へ注入することと， トロッカーを細くすることにより行動範团が広がるた め, 早期に退院できた。

VS-5-8 当院における胆石症に対する基本的治療 戦略と新人の教育方針

東京都立墨東病院外科

真栄城剛，宮本幸雄，田中䓅一，松尾懳，井上暁， 梅北信孝, 吉田操, 北村正次

腹暌鏡下胆摘 (LC)は胆石症に対する標準手術として定 着しており，当院でも最近10年間に胆石症1128例に対し て第一選択として LC を行ってきた. 当院における胆石 症（待期例 - 急性胆炎症例，胆管結石例）に対する手 術，治療方針抢よび治療成績，新人の教育方針を紹介す る.吊り上げ法を基本術式としており，高度肥満例など の特殊例を除いたほほ全例に行っている。本法は元来コ スト面で非常に有利な方法であるが，最近ではさらに胆

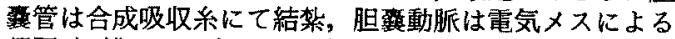
凝固・切離または糸による結禁という方法をとっており， 極力ディスポ製品を使用しない非常にコスト・パフォー マンスの高い手術を実現している。開腹既往症例に対し てもLCを第一選択として行って扔り，胃切除後の症例 でも約 $50 \%$ の完遂率を達成している，急性胆霍炎に対し ては72時間以内の急性期に積極的に LC を施行する方針 をとっており，入院期間の短縮につながっている，総胆 管結石例には結石の大きさ・個数などにより ESTや EPBD とどの内視鏡的アプローチと LC を併用する方法 と腹腔鏡下総胆管切石を使い分けている。新人に対して は 2 年目の研修医に対してカメラ助手を10例経験させた 後, 比較的容易な症例加術者となる。 
VS-5-9 新人に対する教育：鏡視下手術ての鉗子 操作一入門編としての腹空鏡下胆露摘出術における手技 の天

自治医科大学大宮医療センター外科"，博仁会共阊病院 外科 ${ }^{2)}$, 東京北社会保険病院外科 ${ }^{3}$

住永佳久 ${ }^{11}$, 星野徹 ${ }^{2)}$, 宮崎国久 ${ }^{31}$, 遠山信幸 ${ }^{1)}$, 小西文雄 ${ }^{11}$

【はじめに】新人に対する腹腔鏡下胆泰摘出術（以下 LC) の教育は, (1) 特に胆管損傷の回避 (2) 他の鏡視 下手術にも忘用でるる鉜子操作の習熟 (3) 医療材料費 の削隇を念頭に行っている。【目的】鉗子操作による体内 結禁および縫合手技の習得を目標に，鏡視下手術の入門 編とも言える LC で行っている工大を供覧する、【術者の 条件】法者は動物およびトレーニングポックスによる研 修を受け, LCの助手の経験を必要とする.【手技の要点】 始めに肝円索吊上げを左手鉜子操作で行う。胆製管と胆

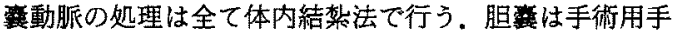
袋に回収し摘出する。【成績】肝円索市り上げは平成 6 年 4 月より，体内結禁による脈管処理は平成13年11月より 基本手技としてきた，従来のクリップによる脈管好理を 行っていた手技と比べて合併症などに差は無いが，手術 時間は従来の88.3土15.4分に対して本術式では107.5士 24.8分と有意に延長した。一方上級者が術者の場合は,

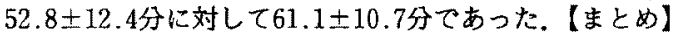
本手技は hand-eye coordination のトレーニングに効 果的であり，他の鏡視下手術手技にも有用と考えている.

VS-6-1 進行胸部食道癌に対する胸筋温存開胸・ HALSによる切除再建術

久留米大学外科

末吉晋，田中寿明，田中優一，笹原弘子，的野吾， 森直樹, 李美慧, 永野剛志, 山名秀明, 白水和雄, 藤田博正

【目的】胸腔鏡下食道切除術が多数の施設で行われるよ うになり，その適応も拡大されつつある。気道系や大動 脈に明らかな浸潤は㒛められなくても, 巨大な T 3 食道 癌では，奇静脈や胸管に浸潤を認めることがある，我々 は胸筋温存開胸に胸腔鏡を併用し手術を施行しているの で供覽する.【症例と手技】症例は55歳男性, MtLt, $8 \mathrm{~cm}$ の 2 型病変で, CTでは左主気管支に接していたが，BF の所見より T 3 と診断した。第 4 助間前方開胸て開胸 し，第 8 肋間中腋窩線上にカメラ用ポートを㨂入した。 術者は主に開胸創より直視下で操作するが, 胸腔鏡の視 野も適宜利用して操作した。本例は奇静脈, 胸管に浸潤 を認めたため，奇静脈弓を切除し，胸管合併切除した。 左主気管支との間は, 腫湟を索引しつつ鋭的に剶離した。 横隔膜上の郭清と剩離は胸腔鏡の視野を利用して行っ た。腹部操作は HALS で行い，上腹部に $7 \mathrm{~cm}$ 開腹し， 看下部にカメラ用ポート，左側腹部に操作用ポートを括 入し，胃管の遊離を行った。再建は胸骨後経路（左鎖骨 骨頭切除) て施行した。【まとめ】我々は T 1 b , T 2 N 0 M 0 症例に胸腔鏡下手術を施行しているが，巨大 T 3 食道癌では，直視下に手指の感触を確かめながらの剝 離操作が必要と考えている。
VS-6-2 進行食道癌に対する胸腔鏡下食道切除術 と胸骨綐切開・上維郭郭清の combination の試み 日本医科大学付属第 2 病院消化器病センター 渡辺昌則, 前島影太郎, 松信哲朗, 吉野雅則, 塩谷猛, 涉谷哲男, 徳永昭

はじめに：胸部食道癌に対して胸整鏡下食道切除遇を導 入して以来，15例に完遂した。鏡視下に郭清不可能な縛 郭リンパ節は無いと考えているので, 当施設での胸腔鉑

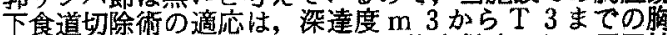
部食道癌としている。し加し，術後合併症として反回神 経麻瘦の频度も少なくなく, 術前より反回神経麻盘老存 寸るような進行癌症例では, このま胸腔鏡下食道切除 術を適応する事に問題があった。そこて, 術前より反回 神経麻舫を有し，上維郭の徽底郭清を必要とするような 進行食道癌症例に対しては，上緶郭りンパ節虽清の徽底， 反回神経温存を耐立させる術式として，胸骨縦切開，上 維㔀郭清先行の胸腔鏡下食道切除術を考案した。少式： 第2 助間までの胸骨部分䓳切開により，直視下に両側の 反回神経を確認, 温存し，徹底した上綎郭の郭清を行引。 時間短縮と体位変擙を 1 回で済ませるために, 同時に再 建鲼管を作成し，胸骨後経路で頚部食道と端々器械勄合 により再建した。体位変換後, 胸腔鏡下に下部繸郭郭清, 食道切除を行い, 小開胸創から食道を摘出した。考察： 直視下に反回神経の確認，温存は容易であり，徹底した 上絀郭郭清が可能であった。術後は, 胸骨骨娟炎の合併 も無人，两側の反回神経住温存されていた今後，症例 の蓄積が必要であるが, 術前反回神経周囲りンパ節転移 による反回神経麻瘦を有する進行食道癌症例には，本布 式も有効な術式の一つとして期待できると思われた。

VS-6-3

胸部進行食道癌に対する鏡視下手術の手 術手技

九州大学臨床・腫演外科

能城浩和，永井英司，清水周次，小島雅之，田中雅夫

【はじめに】多くの施設で胸部食道癌に対しては㸚胸腹 3 領域を十分郭清寸る術式を採用し，これを鏡視下に行 う施設も増えてきた。(目的)今回我々が行つてきた胸部 食道癌に対する鏡視下手術をビデオて供覽する。惠者㧈 上び方法】1998年12月より胸腔鏡下食道切除を76例に施 行した. 胸部操作は第 5 助間に $3 \mathrm{~cm}$ の小切開を扝き 4 ポートで手術を行っている.肺や気管支の压排を行亏特 殊な鈎を用いて十分な術野を得ることが重要である。気 管支動脈怯左右とも可及的に温存し，反回神経や迷走神 経肺枝の取り扱いにも細心の注意を払っている。食道左 側縦隔の郭清のために食道を早期に適切な位置て切碓し て食道端を把持拣引し術野を展開している。後半44例は 腹部操作も鏡視下で行った。【結果】胸腔鏡下食道切除76 例 0 内進行癌 pT 2 が 8 例, pT 3 が24例, pT 4 が 2 例 の計34例が含まれていた。リンパ節転移陽性例は24例 (71\%)方った。進行食道癌34例における平均胸部操作時 間は243分で胸部出血量は $202 \mathrm{ml}$ であった。胸腔内部清り ンパ節個数は25個であった。平均13ヶ月および中央值13 ケ月のの観察期間で手術死亡が 1 例, 在院死亡が 1 例, 癌再発死亡が7例で，6例が再発生存中である，従って 1 年生存が $68 \% ， 2$ 年生存率が $32 \%$ であった。再発13例

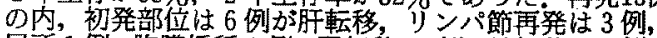
局所 1 例, 胸膜播種 1 例, 腎転移 1 例, 骨転移 1 例て あった。【結語】我々の進行胸部食道癌に対する手術を報 告した. 